\title{
Nexus Between Corporate Social Responsibility, Environmental Disclosure and Financial Reporting Quality Among Listed Firms in Nigeria
}

\author{
Odia Honesty Amenaghawon ${ }^{1}$, Gbenga Ekundayo ${ }^{2}$, Festus Odhigu ${ }^{3} \&$ Mary Josiah $^{1}$ \\ ${ }^{1}$ Department of Accounting, College of Business and Management Studies (CBMS), Igbinedion University, Okada, \\ Nigeria \\ ${ }^{2}$ Department of Administrative and Financial Sciences, Oman College of Management and Technology, Muscat, \\ Oman \\ ${ }^{3}$ Department of Management Studies, Middle East College, Oman \\ Correspondence: Gbenga Ekundayo, Department of Administrative and Financial Sciences, Oman College of \\ Management and Technology, Muscat, Oman.
}

Received: September 20, 2020

Accepted: November 12, 2020

Online Published: January 11, 2021

doi:10.5430/ijfr.v12n2p93

URL: https://doi.org/10.5430/ijfr.v12n2p93

\begin{abstract}
This paper seeks to provide a novel approach and insight into the synergies between corporate social responsibility (CSR), environmental disclosure (ED) and financial reporting quality (FRQ) which is emerging and changing rapidly. The study examined the nexus between corporate social responsibility (CSR), environmental disclosure (ED) and financial reporting quality (FRQ) among corporate entities listed on the Nigeria Stock Exchange (NSE). Data were collected from a sample of 169 listed firms in Nigeria. The research used a panel data set comprising of 624 firm year observations spanning the period 2015 to 2017. The empirical results of the study revealed that there exists a significant relationship between environmental disclosure(ED), firm size (FS), and financial reporting quality (FRQ). However, empirical evidence shows an insignificant relationship between social disclosure (SD), leverage and financial reporting quality (FRQ). We therefore recommend a proposal for the establishment of an inductive corporate social responsibility/environmental disclosure/financial reporting framework that future scientists/scholars can institute to explore the determinants of corporate social responsibility (CSR), environmental disclosure (ED) and financial reporting quality (FRQ) in developing countries.
\end{abstract}

Keywords: corporate social responsibility, environmental disclosure, firm size

\section{Introduction}

Rapid developments in corporate reporting have enabled the nexus between the tripod of corporate social responsibility (CSR), environmental disclosure (ED) and financial reporting quality (FRQ) to broaden in scope and has therefore become a topical issue, which has stimulated the attention of globally renowned scholars and researchers on its antecedents, controversies, and future research agenda which have unravelled truths that are gainful for optimal and effective development in related fields. Issues on these dimensions have cut across a vast spectrum of interwoven sub disciplines such as green finance, environmental sciences and disparate courses inculcating sustainability practices. This spatial distribution informs the application of corporate social responsibility, environmental disclosure and financial reporting quality and makes it suitable for all across the green accounting divide. Consultative and collaboration efforts have been taken by scholars, scientist, practitioners, environmental consultants to steer the course and advance the field on this particular subject domain, with the view of infusing emanating and emerging strands of literature which informs and invigorates the field on this pursuit.

These have led to increasing awareness on the part of firms that success and profit for shareholders do not result from the maximization of short-term profits, but rather from a behaviour that justifies and reinforces social responsibility (Mohammed, Olfa \& Fauzi, 2015). Expositions on corporate social responsibility (CSR) on compartmental debates have been integrated and comprehended to support the adventure and incursion into the new era of corporate reporting. According to Chang, He and Shiao (2015), the concept and dimensions of corporate social responsibility (CSR) are still evolving and too tentative as well as unpredictable to result in a substantially different 
CSR compared to its original meaning. The earlier focus of firms was economy in terms of monetary gains for shareholders, believed to be the primary reason of their existence and operation, a corporate mentality backed by the CSR opportunistic investment concept of the agency theory resulting from information asymmetry. However, the ever dynamic business environment ushered in a transition which left firms with no choice rather than to slowly but surely adopt CSR in their perception. This new thinking translated into proportional concrete evidence of workers welfare improvement. As more confidence is gained in CSR, corporate governance perceives CSR as a core element of long term corporate objective. According to Mohammed et al. (2015) though social accounting was discovered in the 60s, its only concern was the human dimension and in the 1980s it extended to the concern and protection of the environment with the caption of environmental accounting. Chiang et al. (2015) are in agreement with this as they asserted that after the realisation of the interdependence and inseparability of CSR promotion, firms expanded their commitment to actualise their basic profitability objectives and stakeholders' requirements in the light of their environmental protection and social welfare.

The Word Business Council for Sustainable Development reported that core firm values are composed of worker equity, human rights, environmental protection, company participation, relationships with suppliers, transparency, and disclosure as well as stakeholder equity.

The primary purpose of financial statement disclosure is to provide useful or relevant information to stakeholders of firms to make informed decisions. It is a duty within the core of corporate governance to disclose quality financial statements for such purposes. According to Akeju and Babatunde (2017) financial statement quality goes way beyond financial information, it also encapsulates non-financial information as well as disclosure of useful information for making decisions. Alex, John and Brian (2004) posit that CSR is now a front burner management issue as evidenced by the inclusion of several ethical social factors in the Malcolm Baldrige National Quality Award Criteria. Malcolm Baldrige National Quality Award (MBNQA) is an award established by the U.S. Congress in 1987 to promote awareness of quality management and recognition for U.S. companies that implemented successful quality management systems. In the light of this, researchers have continued to examine the possible relationships between CSR disclosure and financial statement quality. Interestingly, there has been remarkable results consistency with respect to claims that there exist some distinctive relationships between CSR practices, disclosure and financial statement quality (Omarah and Imene, 2016; Latonience and Sapkauskiene, 2015; Gajevaszky, 2016; Htay, Said Salman, 2013). Specifically, the work of Herath and Albarqi (2017) on financial reporting quality have variables depicting earnings management, governance practices, internal reporting system, business ethics, CEOs' ages, inside debts holdings, and board size among other factors as influencers of financial reporting qualities. However, the studies unequivocally revealed mixed results with respect to the relationship type. Therefore, the novelty / advancement of the field of this research are encapsulated based on the following scenarios. Paramountly, prior studies have focused on industrialised economies and emerging economies to the detrimental neglect of developing countries. Additionally, previous studies focused on corporate social and environmental disclosure and corporate performance due to the measurability of the characteristics of the variables. This study sheds more insight into the nexus between corporate social responsibility (CSR), environmental disclosure and financial reporting quality, which has been sparsely examined from the perspective of developing economies. Furthermore, new frontiers with regard to the policy implications differentiate this study from the wide variety of studies examined on these interrelated constructs. It is against this back drop, that this study seeks to answer the following research question: What are the determinants for corporate social responsibility, environmental disclosure and financial reporting quality?

The narratives below are indicative of the multi-dimensional components of corporate disclosure which stems from the views of eminent scientists due to the continuous evolving of this multifarious area of specialization.

Financial statement disclosure serves as the basic medium of corporate stewardship to stakeholders. The focus of corporate disclosure has bordered on various aspects such as involuntary, voluntary and mandatory disclosures; financial and non-financial disclosures as well as quality of disclosures (Srinivasa, 2014; Thabit \& Jasmin, 2016).

Corporate social disclosure which is the announcement of financial and non-financial information pertaining to the interface of firms and their environment could have a positive or negative effect on the reporting firm. The disclosure could depict that a firm's operation is in consonance with the environment on the one hand, however, a firm would be presented in a negative light if the disclosure suggests that the operations of the firm is detrimental to the environment (Mohamed et al., 2014). The aim of this paper is to provide a novel approach and insight into the debates surrounding the nexus between corporate social responsibility (CSR), environmental disclosure (ED) and financial reporting quality (FRQ) in the Nigerian context. Flowing from the introduction, section 2 reviews the theoretical framework and sets the conceptual framework associated with corporate social responsibility(CSR), 
environmental disclosure (ED) and financial reporting quality (FRQ),section 3 sheds light on the methodology, section 4 signifies the analysis and the interpretation of the data, while section5 finally draws the conclusion and recommendations.

\section{Literature Review}

\subsection{Theories of Corporate Social Responsibility, Environmental Disclosure and Financial Reporting Quality}

Diverse complementary and supportive theories rooted in the socio-economic domain have held sway in narratives and discussions bordering on corporate social responsibility (CSR), environmental disclosure(ED) and financial reporting quality (FRQ). These include the stakeholder theory, legitimacy theory and agency theory. These theories have given their plausible and dramatic perspectives on this constructs.

Prior empirical and theoretical works have basically been based on these underlying theories such as the aforementioned agency theory, legitimacy theory as well as the stakeholder theory (Chaing et al., 2015; McDermontt, 2011). These underlying theories had their diverse perspectives on the relationship between environmental, social and governance (ESG) disclosure and financial statement quality. These difference in perspectives partly accounts for the mixed results of previous explorations. The agency theory perceives some relationship between corporate social responsibility and financial statement quality which results from information asymmetry as well as opportunistic management. Retrospectively, the theory advocates a separation of leadership structure of the chairman and the chief executive officer (CEO) for effective management which among other benefits, impacts positively on the financial statement quality through superior monitoring of management activities. In this regard, the study of Htlay et al., (2013) revealed that superior disclosure quality in the banking sector can be obtained from separate corporate board leadership structure. In addition, McDermott (2011) documented that by mitigating moral hazard, higher-quality financial reporting improves CSR investment efficiency.

The legitimacy theory is another theory used to account for social and environmental disclosure which Dion and Rui (2014); Mousan and Hassan (2015) opined as the most widely used to explain voluntary social and environmental disclosures in their study of environmental determinants. Legitimacy theory is derived from the concept of organisational legitimacy, a condition which exists when a firm value system is congruent with the value system of the social and larger system of which the firm is a part. One of the several tools of corporate legitimacy assertion is communication which is usually operationalised through the use of financial statement disclosure so as to strike a balance between firm values on the one hand and societal values on the other, to attain a social contract status. Otherwise the firm would acquire negative social impressions detrimental to its corporate existence. An integral part of societal norm and value expectations is the disclosure of quality financial statement for use by society or various stakeholders, the latter being the product of disintegrating the former, that is society, into smaller groups. These smaller groups that make up society happen to be the focus of yet another but similar and complementary theory known as the stakeholder theory. Accordingly Dion et al. (2014) stated that the stakeholder theory is interrelated with the legitimacy theory: while the legitimacy theory concerns its communication with society via its financial statements, the stakeholder theory addresses its communication to the different stakeholders groups. In the light of the focus and connectivity of these theories, this work is therefore predicated on both the legitimacy and stakeholder theories as they form the bedrock of this research due to their alignment and intuitive approach with previous studies bordering on this pertinent issue.

\subsection{Financial Reporting Quality}

This cluster took a comprehensive insight at peer reviewed definitions and established concepts during the course of this investigation from diverse perspectives. These perspectives were mapped out according to their respective domain which has been depicted in the narratives below.

Financial reporting quality transcends beyond financial information. It bifurcates into non-financial information and disclosure useful for making reasonable informed decisions (Akeju \& Babatunde, 2017). The purpose of financial reporting is concerned with the provision of quality information for decision making. In this vein, financial reporting quality is usually construed and deployed in the light of decision- making usefulness of the information provided. Leitoniene and Sapkpauskiene (2015) defined quality as the good properties of an object, its compliance with certain standards. The International Accounting Standard Board (IASB) defined financial reporting quality in terms of fundamental qualitative characteristics of relevance and faithful representation as well as some enhancing characteristics of understandability, comparability, verifiability and timeliness. While these fundamental and enhancing characteristics determine the content of financial reports and positively impact the decision usefulness respectively, they still cannot determine the quality of financial reporting on their own (IASB, 2008). However, the 
characteristics quality was being analysed by Boesse and Kumer (2007) into the type of information as to whether it is qualitative or quantitative; the nature of information as to whether it is financial or nonfinancial, whether it is futuristic or historic. The outlook of Renkas, Goncharenko and Lukianets (2016) stated that financial reporting has a lot of criteria to meet to be considered high quality because the viability or future decision is determined by the quality of information.

According to IASB (2008), relevance refers to the capability of making a difference or impacting the decisions of users as capital providers. By faithful representation annual reports must be complete, neutral and free from material error for it to represent the economic transactions it purports to represent. Understandability is the comprehension of the meaning of financial statements as enabled by the quality of the information which is enhanced through classification, clear and concise presentation. Comparability has to do with the quality of financial statement that enables users to identify similarities in, and dissimilarities between two sets of economic phenomena. Timelines is seen as making information available to decision makers before it loses its capacity to influence decisions.

McDermott (2011) defined financial reporting quality as the precision with which financial reporting conveys information about the firm's operation, in particular its expected cash flow.

Hereath and Albarqi (2017) identified several approaches used to measure and to assess the quality of financial reporting. These approaches include, but not limited to standardised scores, accrual quality or accrual - based models, Beneish Model or M-score, indexes or scores method of internal control, persistence of accruals as well as degree of earnings management.

The significance of the qualitative characteristics of financial reporting quality has been given much stress in various academic literatures (Utami, 2015; Penman, 2007; Salaudeen, Ibikunle \& Chima, 2015; Herath \& Albarqi, 2017). However, Dechow and Dicheu (2002), asserted that operationalising and measuring these qualities are problematic. According to Beest et al. (2009) different financial user groups would have different preferences as well as perceive quality differently. This challenge has therefore accounted for the use of various proxies and indices such as timeliness, earnings management as measures for financial reporting quality, leading to different results achieved from vast spectrum of researches. When looking for the correlation between corporate social responsibility and the quality of financial reports, Jones (1999), Dechov and Dichev (2002), Chiang, He and Shiao (2015) measured financial reporting quality (FRQ) by discretionary accruals and real earnings management of companies. This method examines the level of earnings management as a proxy for earnings quality. It has the credit of easy collection of data in measuring earnings management. However, it has the disadvantage of focusing on earnings quality instead of financial reporting quality. It also suffers from the disadvantage as an indirect measure of financial reporting quality. Hassem (2013) also examines the monitoring characteristics and financial reporting quality (FRQ) of the Nigerian listed manufacturing firms representing FRQ as earnings management using the modified Dechov (2002) model.

\subsection{Social Disclosure and Financial Reporting Quality}

The social dimension is concerned with the perceived roles of firm in society, the expected contribution of business enterprise to society as a reciprocal gesture for its license to operate. This dimension focuses on the relationship with stakeholders which consist of employees, customers, local communities, public and the government and it also includes management of access to products and services, affordability, marketing business practices responsibility, disclosure and labelling as well as privacy and satisfaction of customers.. DeSouza, Flach, Borba and Broietti (2019) investigated financial reporting quality and sustainability information disclosure in Brazil and found that there is no relationship between CSR disclosures and financial reporting quality proxies. Companies that provide high quality financial statements, that is, those that are socially responsible, have less motivation to engage in unethical practices such as earnings management (Ferrero, Sanchez, \& Ballesteros, 2013 ). Flowing from the above inconsistencies, we therefore hypothesise in a null form as follows:

H1: There is no significant relationship between social disclosure and firm size of listed companies in Nigeria.

\subsection{Environmental Disclosure and Financial Reporting Quality}

Corporate environmental disclosure is related with reporting on the impact of firms activities on the natural environment such as waste management, recycling, carbon management, emission, pollution and wildlife conservation (Gatimbu \& Wabwire, 2016). Following the early adoption of environmental accounting in Europe, awareness of the environmental implication of firms' activities has been on the ascendancy, catalysed by several factors especially the resurgence of related literatures and the resultant desire to take advantage of the benefits of environmental accounting and reporting. Alipour, Ghanbari, Jamishnavid and Taherabady (2019) reported a 
significant positive relationship between environmental disclosure and earnings quality. Brahamana, Tan and You (2018) examined environmental disclosure and earnings management and found that CED had a positive and significant effect on EM at $1 \%$ level of significance. This is consistent with the results of Laasaad and Khamoussi (2012). Flowing from the above consistencies, we therefore propose the research hypothesis as follows:

$\mathrm{H} 2$ : There is a significant relationship between environmental disclosure and financial reporting quality of listed companies in Nigeria.

\subsection{Firm Size and Financial Reporting Quality}

The relationship between firm size and financial reporting quality has received substantial empirical consideration. The size of the firm has an extrinsic relationship with financial reporting quality due to the issue of political costs encountered by firms. Proponents are of the candid opinion that larger firms have the likelihood of encountering greater political cost relative to small firms due to intense investors scrutiny deployed by corporate entities (Al-Fayoumi, Abuzaye \&Alexander, 2010). On the other hand, Lobo and Zhou (2006) documented that larger firms have the disposition of managing their earnings due to the complexity of their operations, which makes it difficult for users to detect over statement. Diverse studies have used firm size to represent political costs because there is an intuition that large companies are subjected to intense scrutiny, especially if they are reporting high profits. However, Astami and Tower (2006) found no evidence to support that size influences accounting policy choices in Saudi-Arabia. and the Asian Pacific region. Salehi, Moradi, Bighi and Najiri (2012) explored the relationship between board characteristics and earnings management using a sample of 159 companies listed on the Tehran Stock exchange for four years from 2006 to 2009. The research revealed that firm size does not significantly affect earnings management. We therefore hypothesise in a null form

H3: There is no relationship between firm size and financial reporting quality of listed companies in Nigeria.

\subsection{Leverage and Financial Reporting Quality}

Leverage delineates a company's financial structure and measures the long term risk implied by that structure, which is calculated by company total liabilities divided by total assets (Ofoegbu\&Odoemelan, 2018 \& Palea, 2013). Shehu and Ahmad(2013) explored firms characteristics from the perspective of structure, monitoring, and performance elements and the quality of financial reporting measured by modified model of Deechow and Dichev(2002) of listed manufacturing firms in Nigeria. The study adopted correlational research design with pool balanced panel data of 24 firms employed as sample of the study using multiple regression as a tool of analysis. The empirical results suggest that larger and more leveraged firms in the Nigerian manufacturing sector are less likely to manage earnings and increase in sales as well as institutional investors serving as a monitoring tool of preventing managers from opportunistic behaviour in managing earnings. Prior studies have predominantly used agency theory to explain the relationship between leverage and financial reporting quality (Alsaeed, 2006; Watson et al, 2002). Firms which have higher debt in their capital structure are prone to higher agency cost (Alsaeed, 2006). Consequently, it is argued that leveraged firms have to disclose more information to satisfy information need of the creditors. (Uyar and Kilic, 2012). Therefore,

H4: There is no significant relationship between leverage and financial reporting quality of listed companies in Nigeria.

\section{Methodology}

The research adopted an ex-post facto research design. The adoption of this design was informed by its ability to examine the possible relationship between the dependent and independent variables.

The population of the study is made up of all companies listed on the Nigerian stock Exchange (NSE) amounting to 294 firms as at 29th January, 2019, out of which a sample of 169 firms was drawn with the aid of Yaro Yamane statistical formula spanning a three-year period from 2015 to 2017 with a 5\% error margin. Accruals qualities of the Dechow and Dichev (2002) model was used as proxy for financial reporting quality.

\subsection{Model Specification}

Financial reporting quality $=\mathrm{f}$ (Corporate social disclosure and environmental disclosure)

Integrating the usual control variables of firm size and leverage, we have:

$$
\mathrm{FRQ}=\mathrm{f}(\mathrm{CSR} \text { Disclosure, Environmental Disclosure, Firm Size, LEV) }
$$

In econometric form:

$$
\mathrm{FRQ}=\beta_{0}+\beta \mathrm{CSRD}_{2}+\beta \mathrm{ED}+\beta \mathrm{FSize}+\beta \mathrm{LEV}+\mathrm{U}
$$


Based on the panel data nature of our study, the equation is modified as:

$$
\text { FRQ }{ }_{\text {it }}=\beta_{0}+\beta_{1} \mathrm{CSRD}_{\mathrm{it}}+\beta_{2} \mathrm{ED}_{\mathrm{it}}+\beta_{3} \mathrm{FSize}_{\mathrm{it}}+\beta_{4} \mathrm{LEV}_{\mathrm{it}}+\mathrm{U}_{\mathrm{it}}
$$

Where

FRQ $=$ Financial reporting quality

it $=$ company in year $\mathrm{t}$.

$\beta_{0}=$ the intercept

$\beta_{1}, \beta_{2}, \beta_{3}=$ Coefficients of the independent variables

$\mathrm{U}=$ Error term

\subsection{Data and Measurement}

The research data are essentially from entities listed on the Nigeria Stock Exchange (NSC) between 2015 and 2017. The variables examined comprised of financial reporting quality, corporate social responsibility disclosures, environmental disclosure, firm size and leverage which were computed from the annual reports of the listed entities. Accrual quality was used as a proxy for financial reporting quality. Accrual quality is the level to which working capital accruals map into operating cash flow realisations, where a poor match signifies low accrual quality, a better measure of performance than the underlying cash flows (Dechow \& Dichev, 2002). There is a presumption that high quality earnings emanates from activities that a company will likely be able to sustain in the future and provide an adequate return on the company investment. Corporate social responsibility disclosure (CSRD) was treated as a dichotomous variable and measured taking the value of 1 if items are disclosed in the segment of the annual report pertaining to CSR activities and 0 if otherwise disclosed operationalised by (Mgbame, Mgbame, Akintoye \& Ohalehi, 2019).Environmental disclosure is measured as a dummy variable taking the value of 1 for companies engaged in full environmental accounting disclosure operationalised by (Udoh, 2019). Leverage was also proxied by total debts to total assets operationalised by (Udoh, 2019). Firm size was proxied by the total value of the corporate entities operationalised by (Chowdury \& Chowdury, 2010). The operationalisation of the models has been depicted in the table below.

\subsection{Theoretical Specification of the Model}

\begin{tabular}{lll}
\hline V Ariable & Type & Measurement/Definitions \\
\hline FRQ & Dependent & FRQ proxied by accrual quality \\
\hline CSRD & Independent & $\begin{array}{l}\text { Corporate social responsibility disclosure is treated as a } \\
\text { dichotomous variable. } 1=\text { items disclosed in the section } \\
\text { pertaining to CSR activities. } 0=\text { those not disclosed. }\end{array}$ \\
\hline ED & Independent & $\begin{array}{l}\text { Environmental disclosure. } 1=\text { Companies that engaged in full } \\
\text { environmental accounting disclosure. } 0=\text { Companies that did } \\
\text { not engage in full environmental accounting disclosure. }\end{array}$ \\
\hline FSize & Independent & Firm size was operationalised using log of total assets. \\
\hline LEV & Independent & Leverage proxied by total debts to total assets. \\
\hline
\end{tabular}

Source: Authors Compilation, (2020). 


\section{Estimation Results and Discussions}

4.1 Univariate Analysis \& Descriptive Analysis

Table 1. Results of the descriptive analysis

\begin{tabular}{llllll}
\hline & DSCA & SDI & EDI & LEV & FSIZE \\
\hline Mean & 0.053686 & 0.670059 & 0.148869 & 0.580878 & 6.992965 \\
\hline Median & 0.050000 & 0.625000 & 0.000000 & 0.572824 & 6.940000 \\
\hline Maximum & 0.950000 & 1.000000 & 1.000000 & 0.998566 & 8.980000 \\
\hline Minimum & -0.530000 & 0.000000 & 0.000000 & 0.048108 & 4.960000 \\
\hline Std. Dev. & 0.159993 & 0.207913 & 0.271507 & 0.185795 & 0.796472 \\
\hline Kurtosis & 0.457297 & -0.149329 & 1.710388 & -0.088413 & 0.077099 \\
\hline & 6.635208 & 1.870752 & 4.723042 & 2.425489 & 2.274916 \\
\hline Jarque-Bera & 365.3317 & 35.47432 & 381.4351 & 9.394606 & 14.28760 \\
\hline Probability & 0.000000 & 0.000000 & 0.000000 & 0.009120 & 0.000790 \\
\hline & & & & \\
\hline Sum & 33.50000 & 418.1170 & 92.89400 & 362.4680 & 4363.610 \\
\hline Sum Sq. Dev. & 15.94732 & 26.93099 & 45.92503 & 21.50593 & 395.2112 \\
\hline & & & & \\
\hline Observations & 624 & 624 & 624 & 624 \\
\hline
\end{tabular}

Table 1 presents the results of the descriptive analysis. The mean discretionary accrual is 0.053686 while the mean social disclosure index (SDI) is 0.670059. The mean environmental disclosure index (EDI) is given as 0.148869. The mean leverage is 0.580878 representing about $58 \%$ ratio of total debt to total assets. The mean firm size is 6.9992965 , representing an average firm size of \#7Billion. The result of the descriptive analysis reports very insignificant standard deviations, representing very small dispersion of the variables from their respective mean values. The dependent variable of DSCA reports a standard deviation of (0.159993), SDI (0.207913), EDI (0.271507), LEV (0.185795), and FSIZE (0.796472).

The Jarque-Bera statistics reports relatively large values which is an indication of the normality of the variables of regression. The associated probability values are significant at the 5\% level. The Jarque-Bera (JB) value and the associated probability for the dependent variable of DSCA are 365.3317 (0.000000), SDI 35.47432 (0.000000), EDI 381.4351(0.000000), LEV 9.394606 (0.009120), and FSIZE 14.28760 (0.000790).



Figure 1

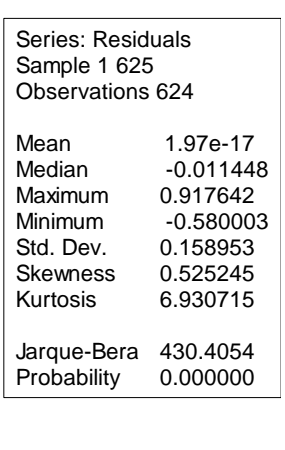

Series: Residuals

Sample 1625

Mean $\quad 1.97 \mathrm{e}-17$

Median $\quad-0.011448$

Minimum $\quad 0.917642$

Std. Dev. $\quad 0.158953$

Skewness $\quad 0.525245$

Jarque-Bera 430.4054

Probability $\quad 0.000000$ 
Figure 1 presents the result of the histogram normality test. The mean JB value is 430.4054 with an associated probability value of $(0.000000)$, indicating that the variables follow the Gaussian normal distribution. The mean kurtosis of 6.930715 is in excess of the benchmark of 3.0 and indicative of leptokurtic distribution, which is evident in the highly-peaked histogram in Figure 1 . The positive skewness of 0.525245 shows that the histogram is skewed to the right.

\subsection{Correlation Analysis}

Table 2. Results of the correlation analysis

\begin{tabular}{|c|c|c|c|c|c|}
\hline \multicolumn{6}{|c|}{ Covariance Analysis: Ordinary } \\
\hline \multicolumn{6}{|c|}{ Date: 02/28/18 Time: 11:01 } \\
\hline \multicolumn{6}{|l|}{ Sample: 1625} \\
\hline \multicolumn{6}{|c|}{ Included observations: 624} \\
\hline \multicolumn{6}{|c|}{ Balanced sample (listwise missing value deletion) } \\
\hline \multicolumn{6}{|l|}{$\overline{\text { Correlation }}$} \\
\hline \multicolumn{6}{|l|}{ t-Statistic } \\
\hline Probability & DSCA & SDI & EDI & LEV & FSIZE \\
\hline \multirow{3}{*}{$\overline{\mathrm{DSCA}}$} & 1.000000 & & & & \\
\hline & ----- & & & & \\
\hline & ----- & & & & \\
\hline \multirow[t]{3}{*}{$\overline{\mathrm{SDI}}$} & 0.029117 & 1.000000 & & & \\
\hline & 0.726493 & ----- & & & \\
\hline & 0.4678 & $\begin{array}{ll}---- \\
\end{array}$ & & & \\
\hline \multirow[t]{3}{*}{$\overline{\text { EDI }}$} & 0.057211 & 0.370772 & 1.000000 & & \\
\hline & 1.429186 & 9.956704 & ----- & & \\
\hline & 0.1535 & 0.0000 & $\begin{array}{c}---- \\
\end{array}$ & & \\
\hline \multirow[t]{3}{*}{$\overline{\mathrm{LEV}}$} & -0.101297 & -0.161415 & -0.094624 & 1.000000 & \\
\hline & -2.539409 & -4.079168 & -2.370565 & ----- & \\
\hline & 0.0113 & 0.0001 & 0.0181 & $\begin{array}{c}---- \\
\end{array}$ & \\
\hline \multirow[t]{3}{*}{ FSIZE } & 0.013318 & 0.384812 & 0.380636 & 0.207452 & 1.000000 \\
\hline & 0.332174 & 10.39788 & 10.26579 & 5.288885 & $\begin{array}{l}---- \\
\end{array}$ \\
\hline & 0.7399 & 0.0000 & 0.0000 & 0.0000 & ---- \\
\hline
\end{tabular}

Table 2 presents the result of the correlation analysis. The correlation coefficients are mixed, with positive correlation between social disclosure index and discretionary accrual (0.029117), environmental disclosure index and discretionary accrual (0.057211), and firm size and discretionary accrual (0.013318). The association between leverage and discretionary accrual is negative (-0.101297). The correlation coefficients are relatively weak and below the benchmark of 10 , and indicative of the absence of the problem of multicollinearity. 
Table 3. Results of the test of variance inflation factor

\begin{tabular}{|c|c|c|c|}
\hline \multicolumn{4}{|c|}{ Variance Inflation Factors } \\
\hline \multicolumn{4}{|c|}{ Date: $02 / 28 / 18 \quad$ Time: $11: 14$} \\
\hline \multicolumn{4}{|l|}{ Sample: 1625} \\
\hline \multicolumn{4}{|c|}{ Included observations: 624} \\
\hline & Coefficient & Uncentered & Centered \\
\hline Variable & Variance & VIF & VIF \\
\hline$\overline{\mathrm{C}}$ & 0.003613 & 88.66125 & NA \\
\hline$\overline{\text { SDI }}$ & 0.001256 & 15.17307 & 1.330620 \\
\hline$\overline{\mathrm{EDI}}$ & 0.000708 & 1.662928 & 1.278073 \\
\hline$\overline{\text { FSIZE }}$ & $9.11 \mathrm{E}-05$ & 110.7582 & 1.416150 \\
\hline$\overline{\mathrm{LEV}}$ & 0.001354 & 12.35396 & 1.144913 \\
\hline
\end{tabular}

The absence of the problem of multicollinearity is further strengthen ed by the result of the test of Variance Inflation Factor (VIF). The centered VIFs are all relatively small and below the benchmark of 10.0 above which is indicative of the problem of multicollinearity. The centered VIF of the variables are: SDI (1.330620), EDI (1.278073), FSIZE (1.416150), and LEV (1.144913). The values are not substantially different from 1.00 and indicates the absence of the problem of multicollinearity.

\subsection{Results of the Regression Diagnostics}

Table 4. Results of the regression diagnostics

\begin{tabular}{lllll}
\hline TEST & TEST TYPE & F-STATISTIC & PROBABILITY & REMARK \\
\hline Serial correlation & Breusch-Godfrey & 1.028455 & 0.0901 & Not Correlated \\
\hline Heteroskedasticity & Breusch-Pagan-Godfrey & 1.538724 & 0.1893 & Homoskedastic \\
\hline Specification & Ramsey RESET & 0.072685 & 0.7876 & Well specified \\
\hline
\end{tabular}

The results of the regression assumption tests are accurate. The serial correlation test using Breusch-Godfrey approach reported a probability value of $0.0901>\mathrm{P}=0.05$ at the $5 \%$ level of significance. The result negates the null hypothesis of serially correlated variables. The result of the test of heteroskedasticity using the Breusch-Pagan-Godfrey test reports a probability value of $0.1893>\mathrm{P}=0.05$ at the $5 \%$ level of significance signifying that the variables are homoskedastic. The result of the Ramsey RESET test for model specification error shows that the regression model is well specified. The test reported a probability value of $0.7876>\mathrm{P}=0.05$ at the $5 \%$ level of significance.

4.4 Multivariate Analysis

Table 5. Result of the regression analysis

Dependent Variable: DSCA

Method: Least Squares

Date: 03/01/18 Time: 14:26

Sample (adjusted): 2625

Included observations: 622 after adjustments

Convergence achieved after 6 iterations

\begin{tabular}{lllll}
\hline Variable & Coefficient & Std. Error & t-Statistic & Prob. \\
\hline
\end{tabular}




\begin{tabular}{lllll}
\hline C & 0.066805 & 0.069179 & 0.965692 & 0.3346 \\
\hline SDI & -0.005072 & 0.038541 & -0.131588 & 0.8954 \\
\hline EDI & 0.025947 & 0.028908 & 0.897574 & 0.3698 \\
\hline FEV & -0.088076 & 0.040132 & -2.194682 & 0.0286 \\
\hline ARIZE & 0.005347 & 0.010807 & 0.494742 & 0.6210 \\
\hline R-squared & 0.163543 & 0.039838 & 4.105234 & 0.0000 \\
\hline Adjusted R-squared & 0.339726 & Mean dependent var & & 0.053553 \\
\hline S.E. of regression & 0.231932 & S.D. dependent var & 0.160050 \\
\hline Sum squared resid & 0.157473 & Akaike info criterion & -0.849520 \\
\hline Log likelihood & 15.27550 & Schwarz criterion & -0.806759 \\
\hline F-statistic & 270.2007 & Hannan-Quinn criter. & & -0.832901 \\
\hline Prob(F-statistic) & 5.096762 & Durbin-Watson stat & 2.019350 \\
\hline Inverted AR Roots & 0.000137 & & \\
\hline
\end{tabular}

Table 5 presents the result of the regression analysis. The multiple coefficient of determination and the adjusted values are $(0.339726)$ and $(0.231932)$ respectively. This indicates that $23 \%$ systematic cross-sectional variation in the dependent variable of financial reporting quality is accounted for by the explanatory variables of social disclosure index and environmental disclosure index. The F-statistic of 5.096762 and the associated probability value of 0.000137 is significant and indicative of linear relationship between the dependent and the explanatory variables. The Durbin-Watson Statistic of 2.019350 is substantially close to the benchmark of 1.00 and indicative of the absence of autocorrelation.

The explanatory variable of social disclosure index is negative signifying that as the level of social disclosure increases, it reduces the tendency for the companies to pursue earnings management. It means the level of earnings management decreases with improved level of social responsibility disclosure. The finding is in tandem with the negative relationship reported by Prior studies De Souza,Flach,Barba and Boretti, (2019), even though overall, the relationship is not statistically significant at the $5 \%$ level having reported a t-value of $(-0.131588)$ and a probability value of (0.8954).

The second explanatory variable of environmental disclosure index is positive, having reported a t-value of $(0.897574)$ and a probability value of $(0.3698)$ at the $5 \%$ level of significance. The implication is that the level of environmental disclosure practiced by the sampled firm is insufficient to reduce earnings management. Instead, the variable increased earnings management even though the extent of increment is not statistically significant. The positive relationship between environmental disclosure index and the dependent variable of discretionary accrual is consistent with the findings of Prior studies such as Aipour, Ghanbari, Jamishnavid \& Tahera (2019); Brahamana, Tan and You, (2019), but inconsistent with the findings reported by Bekiris \& Duokakis, (2011).

The result of the control variable of leverage is negative and statistically significant at the $5 \%$ level. The variable reported a robust $t$-value of (-2.194682) and a significant probability value of (0.0286). It means highly leveraged companies tend to reduce their level of earnings management. The result of firm size is positive implying that larger firms which are very well established tend to be more prone to earnings management. The negative relationship between leverage and financial reporting quality corroborates the position of Shehu and Ahmad (2013) who also reported similar result.

\section{Conclusion and Recommendations}

The fundamental objective of the study is to investigate the nexus between CSR, ED and FRQ among listed firms in Nigeria comprising of 624 firm year observations. The study deployed accrual quality as a proxy for financial reporting quality and regressed it against 4 independent variables (CSR, ED, F size and Lev). The empirical results substantiate a negative relationship between social disclosure, leverage and financial reporting quality, on the other hand, environmental disclosure and firm size both established a significant relationship with financial reporting quality. The findings in this paper advance the belief that firm size has a sine qua non synchronisation with financial 
reporting quality.

Flowing from the findings of the study, the following recommendations have been proffered

The nature of the regulatory framework of corporate social responsibility (CSR) in the Nigeria context should be enhanced and widely implemented by the regulatory authorities in order to inform policy interventions. Noteworthy, regulatory bodies should ensure firms adopt pro corporate social responsibility practices in order for them to achieve and maintain peaceful coexistence with their host communities leading to beneficial symbiotic relationship which will further result in the desired green practices and improved stakeholders relations.

As a result of the antecedents of protagonists, it is widely upheld that large firms have sufficient resources to provide better environmental disclosures to stakeholders than small firms. We therefore concur to this widely held consensus and make a claim for small firms to amalgamate with other existing firms in order to be able to fulfil disclosure mandates accordingly and also to extend supportive leverage as well.

Paradoxically, multiplicity of peer review studies has used different measures of firm size and this appears to be a serious methodological consideration. A composite measure of firm size using indices of total assets, market value and total sales may advance a better measure.

The study unravels and suggests a road map which should be taken into pertinent consideration in enhancing environmental disclosure among corporate entities so that they can optimally and effectively disclose by way of notes to the accounts the extent and valuation of environmental liabilities, environmental costs, greenhouse gas emissions, gas flaring, depletion of natural resources and pollution. Furthermore, the study makes a proposal for the establishment of an inductive corporate social responsibility / environmental disclosure /financial reporting framework that future scientists/scholars can institute to explore the determinants of corporate social responsibility (CSR), environmental disclosure (ED) and financial reporting quality (FRQ) in developing countries. The establishment of this framework would resonate with the widely held views of theoreticians of conceiving testable ideas that can be implemented in future studies and that will be tailored directly to developing countries.

Vast amount of empirical substantiations/ studies had demonstrated the validity of the legitimacy and stakeholder theories in the linkages between CSR, ED and FRQ which apparently have formed the bedrock of this research and we believe this framework constitutes a grounded theoretical foundation that corporate reporting researchers can use for empirical explorations on the distinctive relationship between CSR, ED and FRQ from the perspective of developing countries.

The pivotal contribution / suggestions for future research stems from the notion, that corporate reporting researchers should advance the nexus between Corporate social responsibility (CSR), environmental disclosure (ED) and financial reporting quality (FRQ) to the developing nations as part of the emerging research agenda. Common with most studies, are several constraints- daunting challenges that hindered the progress of the study such as the samples used.

This study used companies listed on the Nigeria Stock Exchange (NSE) and also a limited time horizon spanning the period 2015-2017, which could inhibit the generalisation of the findings. Future studies can delve into a comparative analysis from the perspective of two developing countries context with an expanded time horizon cutting across 2015-2020 which could bolster breakthroughs with enhanced robust findings.

\section{Acknowledgements}

Heartiest appreciation goes to the Department of Administrative and Financial Sciences, Oman College of Management and Technology for providing financial scholarship to embark on this study. Our profound appreciation also goes to the Department of Management Studies, Middle East College Oman and Department of Accounting, Igbinedion University, Okada, Nigeria for the prior research mentoring provided.

\section{References}

Akeju, J. B., \& Babatunde, A. A. (2017). Corporate governance and financial reporting quality in Nigeria. International Journal of Information Research and Review, 4(2), 3749-3753.

Alex, D., John, D., \& Brain, J. (2004). Corporate social reporting in Irish financial institutions. The TQM Magazine, 16(6), 387-395. https://doi.org/10.1108/09544780410563301

Al-Fayomi, N., Abuzayed, B., \& Alexander, D. (2010). Ownership structure and earnings management in emerging markets. The case of Jordan. International Research Journal of Finance and Economics, 38(1), 28-47.

Alipour, M., Ghanbari, M., Jamshidinavid, B., \& Taherabady, A. (2019). The relationship between environmental disclosure quality and earnings quality: A panel study of an emerging market. Journal of Asia Business Studies, 


\section{3(2), 326-347. https://doi.org/10.1108/JABS-03-2018-0084}

Alsaeed, K. (2006). The association between firm specific characteristics and disclosure The case of Saudi Arabia. Managerial Auditing Journal, 21(5), 476-496. https://doi.org/10.1108/02686900610667256

Astami, E. W., \& Tower, G. (2006). Accounting policy and firm characteristics in the Asian Pacific region: An international empirical test of costly contracting theory. The International Journal of Accounting, 4, 1-21. https://doi.org/10.1016/j.intacc.2005.12.004

Beest, F. V., Braam, G., \& Boelens, S. (2009). Quality of Financial Reporting: measuring qualitative characteristics. NICE working paper 09-108. Retrieved from http://www.ru.nl/nice/workingpapers

Brahamana, R. K., Tan, M. Y., \& You, H. W. (2018). Corporate environmental disclosure and earning management. International Journal of Green Economics, 12(3/4), 308-321. https://doi.org/10.1504/IJGE.2018.097874

Chiang, H., He, L., \& Shiao, C. (2015). Financial reporting quality and corporate social responsibility. Asian Economic and Financial Review, 5(3), 453-457. Retrieved from http://www.aessweb.com/journals/5002

Chijoke-Mgbame, A. M., Mgbame, C. O., Akintoye, S., \& Ohalehi, P. (2019). The role of corporate governance on CSR disclosure and firm performance in a voluntary environment. Corporate Governance International Journal of Business in Society, 20(2), 294-306. https://doi.org/10.1108/CG-06-2019-0184

Chowdhury, A., \& Chowdhury, S. P. (2010). Impact of capital structure on firms' value: Evidence from Bangladesh. Business and Economic Horizons, 3(3), 111-122. https://doi.org/10.15208/beh.2010.32

Dechow, P. M., \& Dichev, I. D. (2002). The quality of accruals and earnings. The role of the estimation errors. The Accounting Review, Supplement, 77, 35-59. https://doi.org/10.2308/accr.2002.77.s-1.35

DeSouza, J. A., Flach, L., Borba, J. A., \& Broichetti. (2019). Financial reporting quality and sustainability information disclosure in Brazil. Brazilian Business Review, 16(6), 556-575. https://doi.org/10.15728/bbr.2019.16.6.2

Dion, B., \& Rui, J. O. (2014). Environmental disclosure determinants in Dutch listed companies. Revista Contabilidade and Fiancas.

Ferrero, J. M., Sanchez, I. M. G., \& Ballesteros, B. C. (2014). Effect of financial reporting quality on sustainability information disclosure. Corporate Social Responsibility and Environmental Management, 22(1), 45-64. https://doi.org/10.1002/csr.1330

Gajevszky, A. (2016). Do specific corporate governance attributes contribute to the quality of financial reporting: evidence from Romania. Journal of Economics, Business and Management, 4(1), 15-22. https://doi.org/10.7763/JOEBM.2016.V4.360

Gatmimbu, K. K., \& Wabwire, J. M. (2016). Effects of corporate environmental disclosure on financial performance of firms listed at Nairobi Securities and Exchange, Kanya. International Journal of Sustainability Management and Information Tecnologies, 2(1), 1-6.

Hassan, S. U. (2013). Financial reporting quality, does monitoring characteristics matter? An empirical analysis of Nigeria Manufacturing Sector. The Business and Management Review, 3(2), 147-161.

Herath, S. K., \& Albargi, N. (2017). Financial reporting quality: A literature review. International Journal of Business Management and Commerce, 2(2), 1-14.

IASB. (2008). Exposure Draft on an improved Conceptual Framework for Financial Reporting. The Objective of Financial Reporting and Qualitative Characteristics of Decision useful Financial Reporting Information, London.

Itlay, S. N., Said, R. M., \& Salman, S. A. (2013). Impact of Corporate governance on disclosure quality: empirical evidence from listed banks in Malaysia. International Journal of Economics and Management, 7(2), 242-279.

Kiai, N., \& Omri, A. (2011). Corporate Governance and Financial Reporting Quality: The case of Tunisian firms. International Business Research, 4(1), 158-166. https://doi.org/10.5539/ibr.v4n1p158

Lassaad, B., \& Khamoussi, H. (2012). Environmental and social disclosure and earnings persistence. International Journal of Social Science \& Interdisciplinary Research, 1(7), 20-42.

Leitoniene, S., \& Sapkauskiene, A. (2015). Quality of corporate social responsibility information. 20th International Scientific Conference Economics and Management. Procedia Social and Behavioural Science, 213, 334-339. Retrieved from http://creativecommons.org/licenses/by-nc-nd/4.0/

Lobo, G. J., \& Zhou, J. (2006). Did conservatism in financial reporting increase after the Sarbanes Oxyley Act: 
Initial evidence. Accounting Horizons, 20(1), 57-73. https://doi.org/10.2308/acch.2006.20.1.57

MeDermott, K. E. (2012). Financial reporting qualities and investment in corporate social responsibility. Asian Economic and Financial Review, 5(3), 453-467. Retrieved from http://www.aessweb.com/journals/5002

Mohamed, T., Olfa, B. J., \& Faouzi, J. (2015). Corporate Social Disclosure: explanatory theories and conceptual framework. International Journal of Academic Research in Management, 3(2), 208-225.

Mousa, G. A., \& Hassan, N. T. (2015). Legitimacy theory and environmental practices: short notes. International Journal of Business and Statistical Analysis, 2(1), 42-53. https://doi.org/10.12785/IJBSA/020104

Ofoegbu, N. G., \& Odoemelam, N. (2018). International financial reporting standards (IFRS) disclosure and performance of Nigeria listed companies. Cogent Business and Management, 5(1), 1-18. https://doi.org/10.1080/23311975.2018.1542967

Onuorah, A. C., \& Imene, O. F. (2016). Corporate governance and financial reporting quality in selected Nigerian company. International Journal of Management Science and Business Administration, 2(3), 7-16. https://doi.org/10.18775/ijmsba.1849-5664-5419.2014.23.1001

Palea, V. (2013). IAS/IFRS and financial reporting quality: Lessons from the European experience. China Journal of Accounting Research, 6(4), 247-263. https://doi.org/10.1016/j.cjar.2013.08.003

Penman, S. H. (2007). Financial reporting quality: is fair value a plus or a minus?. Accounting and Business Research Special Issue: International Accounting Policy Forum, 33-44. https://doi.org/10.1080/00014788.2007.9730083

Renkas, J., Gonccharenko, O., \& Lukiants, O. (2016). Quality of Financial Reporting: approaches to measuring. International Journal of Accounting and Economics Studies, 4(1), 1-5. https://doi.org/10.14419/ijaes.v4i1.5509

Salaudeen, Y. M., \& Ibikunle, J. E. (2015). Unethical Accounting Practice and Financial Reporting Quality: evidence from Nigeria. International Journal of Academic Research in Accounting, Financial and Management Sciences, 5(2), 143-150. https://doi.org/10.6007/IJARAFMS/v5-i2/1689

Salehi, M., Bighi, S. J. H., \& Najiri, M. (2012). A study of relationship between board characteristics and earnings management. Universal Journal of Management and Social Sciences, 23(2), 12-29.

Shehu, U. H., \& Ahmad, B. (2013). Firm characteristics and financial reporting quality. A case of Nigerian Manufacturing Firms. International Journal of Accounting, Banking and Management, 1(6), 47-63.

Srinivasa, M. (2014). Conceptual Framework of Environmental Accounting and reporting: An overview. International Journal of Economic and Business, 3(2), 43-51.

Sustainability Accounting Standard Board. (2013). Conceptual Framework of the Sustainability Accounting standards Board.

Thabit, H. T., \& Jasim, Y. A. (2016). The Role of Environmental Accounting disclosure to reduce harmful emissions of oil refining companies. Zanco Journal of Pure and Applies Sciences, 28(6), 50-60.

Udoh, E. J. (2019). Environmental accounting disclosure practices in annual reports of listed oil and gas companies in Nigeria. International Journal of Accounting and Finance, 8(1), 2-21.

Utami, W. (2015). Financial Performance and the quality of sustainability disclosure based on global reporting initiative value relevance study in Indonesia Stock Exchange. Mediterranean Journal of Social Sciences MCSER Publishing, Rome-Italy, 6(5), 5. https://doi.org/10.5901/mjss.2015.v6n5s5p243

Uyar, A., \& Kilic, M. (2012). The influence of firm characteristics on disclosure of financial ratios in annual reports of Turkish firms listed in the Istanbul stock exchange. International Journal of Accounting, Auditing and Performance Evaluation, 8(2), 137-156. https://doi.org/10.1504/IJAAPE.2012.046603

Watson, A., Shrives, P., \& Marston, C. (2002). Voluntary disclosure of accounting ratios in the UK. British Accounting Review, 34, 289-313. https://doi.org/10.1006/bare.2002.0213

\section{Copyrights}

Copyright for this article is retained by the author(s), with first publication rights granted to the journal.

This is an open-access article distributed under the terms and conditions of the Creative Commons Attribution license (http://creativecommons.org/licenses/by/4.0/). 